\title{
Ethnicity in the 1940 Presidential \\ Election in Iowa: A Quantitative Approach
}

Thomas G. Ryan

ALTHOUgh HE WON AN UNPRECEDENTED THIRD TERM IN THE 1940 presidential election, Franklin D. Roosevelt ran well behind his landslide 1936 vote, prompting questions of who voted for Roosevelt in 1936 but not in 1940, and why did the Roosevelt vote fall so sharply between the two elections? ${ }^{1}$

Previous studies of the 1940 election cite German-Americans as the principal agents in the decreased Democratic presidential vote, arguing that German-Americans voted considerably less strongly for Roosevelt in 1940 than in 1936 because of his anti-German, pro-English foreign policy. ${ }^{2}$ Interpretations of 1940 voting behavior which emphasize the roles of ethnicity and of foreign policy considerations in that election also list Italian-Americans, Irish-Americans, and Roman Catholics in general as other important participants in the movement away from Roosevelt in $1940 .^{3}$

${ }^{1}$ Roosevelt's share of the total popular vote fell from $60.8 \%$ in 1936 to $54.7 \%$ in 1940 , while his electoral vote decreased from 523 to 449 , as he carried forty-six states in 1936 and forty in 1940. Svend Petersen, A Statistical History of the American Presidential Elections (New York, 1963), 94-98.

${ }^{2}$ Among the works which emphasize the role of German-Americans in decreasing the Democratic presidential vote in 1940 are Samuel Lubell, The Future of American Politics (3d ed., rev., New York, 1965), 131-155; James MacGregor Burns, Roosevelt: The Lion and the Fox (New York, 1956), 455; Robert A. Divine, Foreign Policy and U.S. Presidential Elections, 19401948 (New York, 1974) 86; Ellsworth Barnard, Wendell Willkie: Fighter for Freedom (Marquette, 1966), 265; Robert W. Cherny, "Isolationist Voting in 1940: A Statistical Analysis," Nebraska History, 52 (Fall 1971), 293-309; and Howard W. Allen, "Isolationism and GermanAmericans," Journal of the Illinois State Historical Society, LVII (Summer 1964), 143-149.

${ }^{3}$ Samuel Lubell, Revolt of the Moderates (New York, 1956), 80; Harold F. Gosnell, Champion Campaigner: Franklin D. Roosevelt (New York, 1952), 187; Warren Moscow, Roosevelt and Willkie (Englewood Cliffs, 1968), 197.

A useful definition of "ethnic group" is: "A collectivity within a larger society having real or putative common ancestry, memories of a shared historical past and a cultural focus on one or more symbolic elements defined as the epitome of its peoplehood." R. A. Schermerhorn, Comparative Ethnic Relations: A Framework for Theory and Research (New York, 1970), 12-17, 
While most attempts to explain changes in voting behavior between 1936 and 1940 emphasize ethnicity and foreign policy as the chief factors in the decreased Democratic presidential vote, some accounts of the election find the sources of the increased Republican vote in the defection of middle western farmers and of upper-income citizens, both of whom are alleged to have deserted Roosevelt in large numbers between 1936 and $1940 .{ }^{4}$ However, the few studies which do find economic explanations for some of the decrease in the Democratic presidential vote also list German-Americans as an important element in the Willkie coalition, thereby merging ethnic-foreign policy and economic-domestic policy considerations.

Despite the widespread agreement among historians that members of specific nationality and religious groups contributed disproportionately to the increased Republican presidential vote in 1940 , little systematic analysis of demographic or of voting data has been presented to support such contentions. Although the voters rendered the verdict in the Roosevelt-Willkie contest, as in other presidential elections, they are almost invisible in accounts of the 1940 election.

This study of the 1936-1940 voting behavior ${ }^{5}$ of specific groups in Iowa attempts to ". . . use . . . local history to test traditional assumptions and large generalizations," " about the roles of nationality, religion, and size of community in the third Roosevelt election. The evidence confirms traditional assumptions regarding the large-scale defection of German-

quoted in John L. Shover, "Ethnicity and Religion in Philadelphia Politics, 1924-1940," American Quarterly, XXV (December 1973), 500-501. At least one authority suggests that "Every American, as we shall use the term, is a member or potential member of an ethnic group-racial, religious, or national origin." Charles H. Anderson, White Protestant Americans: From National Origins to Religious Group (Englewood Cliffs, 1970), xiii.

4Gosnell, Champion Campaigner, 187; "Gallup and Fortune Polls," Public Opinion Quarterly, 5 (March 1941), 147; Robert E. Burke, "Election of 1940," History of American Presidential Elections, 1789-1968, ed. Arthur M. Schlesinger, Jr., IV (New York, 1971), 2946.

"Throughout this paper, the phrase "1936-1940 voting behavior" refers to the amount of change in the Democratic percentage of the presidential vote between 1936 and 1940.

'Michael Kammen, "Politics, Science, and Society in Colonial America: An Essay Review of Recent Approaches and Neglected Opportunities," Journal of Social History, 3 (Fall 1969), 78. 
Americans from Roosevelt. It offers little support, however, for interpretations such as those of Robert E. Burke or Malcolm Moos, which attribute Democratic losses to farmers, or for the interpretations of Harold F. Gosnell or of Warren Moscow, ${ }^{7}$ which emphasize the defection of Roman Catholics from the Roosevelt coalition.

Statewide there was a decline of $6.8 \%$ in the vote for Roosevelt between the 1936 and 1940 elections. Changes in Roosevelt's share of the vote ranged from an increase of $0.9 \%$ (in Webster County) to a decrease of $23.1 \%$ (in Bremer County). The wide range suggests that voters in this seemingly homogeneous state responded in varied ways to the 1940 political situation. ${ }^{8}$ Table I indicates the number of counties in which Roosevelt's share of the vote increased or decreased specific amounts between 1936 and 1940. Although his vote decreased in ninety-eight of the ninety-nine counties, the size of the decrease varied considerably from county to county.

Several factors influenced this range in the 1936-1940 voting behavior of Iowa counties. One thing is clear: counties with large numbers of first- and second-generation GermanAmericans recorded greater declines in the vote for Roosevelt in 1940 than did counties with smaller proportions of firstand second-generation German-Americans. The relationship between the size of the German-American population in each county and the size of the decrease in the Democratic presidential vote was not linear, but, as Table II shows, the larger

Some recent studies of nineteenth century voting behavior suggest that investigations of popular voting can be combined with studies of political elites to enlarge our understanding of the American political experience. Among the best known recent works are Lee Benson, The Concept of Jacksonian Democracy: New York as a Test Case (Princeton, 1961); Richard J. Jensen, The Winning of the Midwest: Social and Political Conflict, 1888-1896 (Chicago, 1971); Paul Kleppner, The Cross of Culture: A Social Analysis of Midwestern Politics, 1850-1900 (New York, 1970); and Samuel T. McSeveney, The Politics of Depression: Political Behavior in the Northeast, 1893-1896 (New York, 1972).

7"Election of 1940," 2946; The Republicans: A History of Their Party (New York, 1956), 418-419; Champion Campaigner, 187; Roosevelt and Willkie, 197.

'Unless indicated otherwise, all changes in voting behavior are based on the total, rather than the two-party, vote. Arnold Rogow, "The Loyalty Oath Issue in Iowa, 1951," American Political Science Review, LV (December 1961), 869, notes that "Political, economic, and social homogeneity have been more characteristic of Iowa than of a large number of other states." In addition, Iowa has few non-whites and few immigrants from southern or eastern Europe. 


\section{TABLE I}

Number of Iowa Counties in which the Democratic Presidential Vote Increased/Decreased Specific Amounts, 1936-1940a

\begin{tabular}{lrr} 
& \multicolumn{2}{l}{$\begin{array}{l}\text { Change in Democratic } \\
\text { Presidential Vote }\end{array}$} \\
\cline { 2 - 3 } Increased & $0.1-4.9 \%$ & 1 county $(\mathrm{N}=1) *$ \\
Decreased & $0.1-4.9 \%$ & 32 counties $(\mathrm{N}=32)$ \\
Decreased & $5.0-9.9 \%$ & 39 counties $(\mathrm{N}=39)$ \\
Decreased & $10.0-14.9 \%$ & 17 counties $(\mathrm{N}=17)$ \\
Decreased & $15.0-19.9 \%$ & 8 counties $(\mathrm{N}=8)$ \\
Decreased & $20.0-24.9 \%$ & 2 counties $(\mathrm{N}=2)$
\end{tabular}

a State of Iowa, Official Register, 1937-1938 (Des Moines, n.d.), 312-313. Official Register, 1941-1942 (n.d.), 652-653.

*In all subsequent tables, the symbol $\mathrm{N}=$ indicates the number of counties or cities in each category.

the German foreign stock population in each group of counties, the larger the decrease in the Democratic percentage of the presidential vote. In the thirty-nine counties where firstand second-generation German-Americans were less than $8.0 \%$ of the total population, Roosevelt's presidential vote decreased only $4.4 \%$. This was less than one-third the decrease in the most German counties in the state. In the nine counties where first- and second-generation Germans were $24.0-31.9 \%$ of the total population, Roosevelt's vote declined $16.0 \%$.

There is considerably less evidence to show that the president lost Iowa because of an agrarian revolt. ${ }^{9}$ While Iowa farmers decreased their Democratic presidential vote somewhat more than other Iowans, $\mathbf{1 1 . 3 \%}$ compared with a statewide decrease of $6.8 \%$, the uneven incidence of Roosevelt's farm losses suggests that factors other than specifically agrarian discontent explain the pattern of Democratic decreases in the Iowa farm vote. ${ }^{10}$ Table III indicates the wide

'Among the studies which emphasize agrarian discontent as a primary cause of Democratic losses in 1940 are Moos, The Republicans, 418-419; Burke, "Election of 1940," 2946; and George M. Mayer, The Republican Party, 1854-1966 (2d ed., New York, 1967), 460.

${ }^{10} \mathrm{The}$ farm vote for each county was determined from the vote of all precincts which contained no community of over 1,000 population. Because over three-fourths $(\mathbf{7 5 . 3 \%})$ of all Iowans living in this type of precinct in 1930 lived on farms, the farm vote reported here was overwhelmingly the vote of farmers rather than residents of rural non-farm communities. The proportion of 


\section{TABLE II}

Decrease in the Democratic Percentage of the Presidential Vote by Iowa Counties, 1936-1940, by German Foreign Stock Percentage of the Total Population, $1930^{\mathrm{b} *}$

$\underline{\text { German Foreign Stock }}$

$$
\begin{array}{r}
0-7.9 \% \\
8.0-15.9 \% \\
16.0-23.9 \% \\
24.0-31.9 \%
\end{array}
$$

Average Decrease

in Democratic

Presidential Vote

\begin{aligned} \hline $4.4 \% & (\mathrm{~N}=39) \\ 7.2 \% & (\mathrm{~N}=30) \\ 10.3 \% & (\mathrm{~N}=21) \\ 16.0 \% & (\mathrm{~N}=9)\end{aligned}$

bUnited States Department of Commerce, Bureau of the Census, Fifteenth Census of the United States: 1930 Population, Volume III, Part I (Washington, 1932), 785-788. Official Register, 1937-1938, 312-313, 1941 1942, 652-653.

*Because the 1940 census listed the country of birth only for the foreignborn white in each Iowa county, the 1930 census was used to establish the German foreign stock in each county because it listed both the country of birth of the foreign born and the country of birth of the foreign-born parents of the native born of foreign or mixed parentage.

range in the 1936-1940 voting behavior of Iowa farmers, as those living in Linn County decreased their vote for Roosevelt only $1.1 \%$, while Plymouth County farmers voted $32.3 \%$ less Democratic in 1940 than in 1936. In addition to Linn County, farmers in seventeen other counties decreased their Democratic presidential vote less than $5.0 \%$. At the other extreme, farmers in nine additional counties joined Plymouth County farmers in decreasing their Democratic presidential vote $20.0 \%$ or more.

Ethnicity appears to be the more plausible explanation of 1936-1940 voting behavior. An examination of Table IV reveals that the 1940 "farm revolt" in Iowa was concentrated in

the population in these farm precincts which actually lived on farms ranged from $82.7 \%$ in Plymouth County to $60.7 \%$ in Dallas County.

Because the Iowa Official Register reported the precinct vote for only the two major parties in the 1936 and 1940 elections, while it listed the total vote cast statewide, and in each county, the figures in the text exaggerate the size of the decrease in Roosevelt's share of the farm vote compared with the decrease in his proportion of the statewide vote. When the two-party vote is used to determine Roosevelt's losses among both electorates, his statewide decrease is $8.2 \%$ (rather than $6.8 \%$ ), compared with $11.3 \%$ among farmers. 


\section{TABLE III}

Number of Iowa Counties in which the Democratic Percentage of the Farm Vote for President Decreased Specific Amounts, 1936-1940c

Decrease in Democratic

Farm Vote

\begin{aligned} \hline $0.1-4.9 \% & (\mathrm{~N}=18) \\ 5.0-9.9 \% & (\mathrm{~N}=32) \\ 10.0-14.9 \% & (\mathrm{~N}=27) \\ 15.0-19.9 \% & (\mathrm{~N}=12) \\ 20.0-24.9 \% & (\mathrm{~N}=7) \\ 25.0-29.9 \% & (\mathrm{~N}=2) \\ 30.0-34.9 \% & (\mathrm{~N}=1)\end{aligned}$

'Official Register, 1933-1934, 262-268; Official Register, 1937-1938, 224311; Official Register, 1941-1942, 560-647.

counties with large numbers of first- and second-generation German-Americans. In the nine counties with the largest proportions of German foreign stock $(24.0-31.9 \%$ of the total population), the decrease in the Democratic percentage of the farm vote for president was over three times the decrease in the thirty-nine counties where first- and second-generation German-Americans were least numerous (less than $8.0 \%$ of the total population). Roosevelt's farm vote fell only $6.1 \%$ in the least-German counties compared with $19.6 \%$ in the mostGerman counties. ${ }^{11}$

The data indicates that, at least in Iowa, the widelyheralded agrarian protest was, in reality, part of a movement against Roosevelt by voters in areas with significant GermanAmerican populations. There is little evidence of a " farm revolt" in Iowa counties with few German-Americans. The role of German-Americans in the 1940 presidential election can be

${ }^{11}$ Because the census reports the national origins of immigrants and of their children only for counties, and for cities of at least 10,000 population, no exact data regarding the national origins of the farm population, as distinct from the entire county population, are available. However, the evidence suggests strongly that the proportion of farm residents in Iowa counties who were first- or second-generation German-Americans was quite similar to the proportion of all residents of the same counties who were first- or second-generation German-Americans, with somewhat higher proportions of German-Americans living on farms than in cities throughout the state. See Table V for more detailed information regarding the proportions of German-Americans living in Iowa cities, Iowa rural counties and Iowa urban counties. 


\section{TABLE IV}

Decrease in the Democratic Percentage of the Farm Vote for President by Iowa Counties, 1936-1940, by the German Foreign Stock Percentage of the Total Population, 1930d

German Foreign Stock

$$
\begin{array}{r}
0.1-7.9 \% \\
8.0-15.9 \% \\
16.0-23.9 \% \\
24.0-31.9 \%
\end{array}
$$

Decrease in Democratic Farm

Vote for President

$$
\begin{aligned}
6.1 \% & (\mathrm{~N}=39) \\
11.0 \% & (\mathrm{~N}=30) \\
16.4 \% & (\mathrm{~N}=21) \\
19.6 \% & (\mathrm{~N}=9)
\end{aligned}
$$

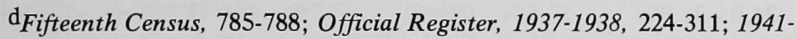
1942, 560-647.

studied further by comparing voting patterns in rural and in urban German-American areas, as well as voting patterns in German-Protestant and German-Catholic areas.

Although both rural and urban areas with large numbers of German-Americans turned against Roosevelt in 1940 to a greater extent than similar areas with few German-Americans, Table $V$ indicates that the relationship between German ancestry and voting behavior was particularly strong in rural areas. The Democratic percentage of the presidential vote fell off more noticeably in rural counties with given proportions of first- and second-generation German-Americans than in either urban counties or cities with similar proportions of German-Americans. In rural counties where the German foreign stock was less than $8.0 \%$ of the total population, Roosevelt's vote decreased $4.4 \%$, compared with only $1.7 \%$ in urban counties with similar proportions of German-Americans. At the other end of the scale, in counties where first- and secondgeneration German-Americans were $24.0-31.9 \%$ of the total population, a similar relationship between voting behavior in rural and in urban counties existed. There, rural counties decreased their Democratic presidential vote $17.5 \%$, compared with only $7.7 \%$ in urban counties.

Table $\mathrm{V}$ shows a relatively larger concentration of German-Americans in rural counties than in either urban 


\section{TABLE V}

Decrease in the Democratic Percentage of the Presidential Vote, 1936-1940, by Iowa Rural Counties, Urban Counties, and Cities,* by German Foreign Stock Percentage of the Total Population, 1930

German Foreign

\begin{tabular}{r} 
Stock \\
\hline $0-7.9 \%$ \\
$8.0-15.9 \%$ \\
$16.0-23.9 \%$ \\
$24.0-31.9 \%$
\end{tabular}

Decrease in Democratic Percentage of Presidential Vote

\begin{tabular}{|c|c|c|c|c|c|}
\hline \multicolumn{2}{|c|}{ Rural Counties } & \multicolumn{2}{|c|}{ Urban Counties } & \multicolumn{2}{|c|}{ Cities } \\
\hline $4.4 \%$ & $(\mathrm{~N}=11)$ & & $(\mathrm{N}=5)$ & & $(\mathrm{N}=10)$ \\
\hline $7.1 \%$ & $(\mathrm{~N}=8)$ & $4.7 \%$ & $(\mathrm{~N}=6)$ & $2.5 \%$ & $(\mathrm{~N}=6)$ \\
\hline $11.2 \%$ & $(\mathrm{~N}=6)$ & $8.7 \%$ & $(\mathrm{~N}=4)$ & $9.2 \%$ & $(\mathrm{~N}=5)$ \\
\hline $17.5 \%$ & $(\mathrm{~N}=5)$ & $7.7 \%$ & $(\mathrm{~N}=1)$ & $\longrightarrow$ & - \\
\hline
\end{tabular}

*."Rural Counties" had no community over 2,499 population in 1930.

"Urban Counties" had at least one-half of their population in cities of 10,000 and up in 1930.

"Cities" includes all communities of 10,000 and up in 1930. A 10,000 population figure was used for "cities" because the 1930 census lists the country of birth for the foreign born and for the foreign-born parents of the native born only for counties and for communities of 10,000 and up. Comparable information for smaller communities is not available.

The smaller Democratic decrease in "urban counties" than in "cities" reflects the fact that the county decreases are based on changes in the total vote, while the city decreases are of the two-party vote, the only voting data available for city precincts. When changes in the "urban county" and in the "city" vote are calculated on the same (two-party) basis, Roosevelt's urban county losses are larger than those in the cities. The decreases in his share of the two-party vote in the four categories of urban counties, from the least German to the most German, respectively, were $3.0 \%, 6.5 \%, 12.8 \%$, and $8.8 \%$.

EFifteenth Census, 785-788; Official Register, 1933-1934, 262-268; 19371938, 224-311; 1941-1942, 560-647.

counties or cities. Three-eighths $(36.7 \%)$ of rural counties had a German foreign stock that was at least $16.0 \%$ of the total population, compared with only one-third of urban counties $(31.3 \%)$, and one-fourth $(23.8 \%)$ of cities.

The relationship between community size, German ancestry, and 1936-1940 voting behavior suggests that the role of ethnicity in the third Roosevelt election was more complex than earlier writers realized. Despite Samuel Lubell's assertion that "... this German-American swing [away from Roosevelt was not] merely an agricultural one [because] post- 
election surveys in $1940 \ldots$ showed the same pattern for German-American precincts in the cities," 12 the Iowa data indicates that Roosevelt's vote decreased more in rural than in urban areas with given concentrations of German-Americans. Lubell supplies no data to support his conclusion, while other authors who emphasize the role of German-Americans in decreasing Roosevelt's vote do not even consider the question of community size. ${ }^{13}$ The Iowa findings indicate a need to study other states, in an attempt to determine if community size was significant elsewhere.

Despite the differences in the $1936-1940$ voting behavior of equally-German rural and urban areas in Iowa, a positive relationship between the size of the German-American population and the size of the decrease in the Democratic presidential vote prevailed in both types of areas. At least in Iowa, the size of the German-American population was more closely related to 1936-1940 voting behavior than was the size of the community, as rural and urban areas with large numbers of German-Americans moved away from Roosevelt in 1940 more than rural or urban areas with few German-Americans. Ethnicity, in the form of German ancestry, appears to have been more important than size of community.

Interpretations which emphasize ethnicity as a determining factor in 1936-1940 voting behavior concentrate on GermanAmericans. However, they also assert that Italian-Americans, Irish-Americans, and Roman Catholics in general, joined German-Americans in giving Roosevelt a significantly smaller share of their vote than they had four years earlier. ${ }^{14} \mathrm{O}$ these additional groups of anti-Roosevelt voters, Catholics are the most visible and thus the most accessible for an analysis of

${ }^{12}$ Lubell, Future American, 135.

${ }^{13}$ Burns, Roosevelt, Lion and Fox, 455; Divine, Foreign Policy, 86; Barnard, Wendell Willkie, 265.

${ }^{14}$ Among the writers who attribute much of the decrease in Roosevelt's vote between 1936 and 1940 to Irish-Americans, to Italian-Americans, and to Roman Catholics in general, as well as to German-Americans, are Gosnell, Champion Campaigner, 187; Moscow, Roosevelt and Willkie, 197; Lubell, Revolt Moderates, 80; and Otis L. Graham, "The Democratic Party, 1932 1945,” History of U.S. Political Parties, ed. Arthur M. Schlesinger, Jr., III (New York, 1973), 1953. 
1936-1940 voting behavior in Iowa. ${ }^{15}$

Among the groups usually described as responsible for the decline in the Democratic presidential vote in 1940, Catholics are second only to German-Americans. Harold F. Gosnell notes that "Among religious groups, Roosevelt dropped off most among Catholics;" Warren Moscow concludes that "Irish Catholic Democrats departed the Democratic Party in large numbers in 1940;" and Lubell maintains that Roosevelt's ". . . heaviest losses were among voters of German, Italian, or Irish ancestry," the latter two overwhelmingly Catholic, the first somewhat more Protestant than Catholic. ${ }^{16}$

Although German-Americans are probably more evenly divided between Catholicism and Protestantism than the members of any other large national group in the United States, published accounts of 1936-1940 voting behavior which emphasize the role of ethnicity fail to mention that characteristic of German-Americans. Lubell uses "German" and "Catholic" in such a way as to suggest that the two groups were almost identical. ${ }^{17}$ This usage overlooks both the Protestant majority among German-Americans and the minority status of Germans among American Catholics.

The traditional view that Roman Catholics contributed more than any other religious group to Roosevelt's losses in 1940 is not supported by an examination of the Iowa vote. As Table VI demonstrates, the Roosevelt vote in Iowa declined somewhat more in counties with large numbers of Lutherans

${ }^{15}$ Although Irish-Americans were relatively numerous in nineteenth century Iowa, they have always been a far smaller group in the state than German-Americans, and, by 1940 , were too few and too scattered to permit a meaningful analysis of the vote of first- and second-generation Irish-Americans at the county level. The census of 1930 reported only 47,282 first- or secondgeneration Irish-Americans in Iowa, compared with six times as many German-Americans287,663 .

Italian-Americans and most other southern and eastern European immigrants have never been numerous in Iowa. In 1930, there was only one first- or second-generation Italian-American for every twenty-nine German-Americans, 9,747 compared with 287,663. For an analysis of 1936-1940 Italian-American and Irish-American voting behavior in Philadelphia, see Thomas G. Ryan, "Ethnicity, Quantification and Voting Behavior" (unpublished paper available from the author), 13-16.

${ }^{16}$ Champion Campaigner, 187; Roosevelt and Willkie, 197; Revolt Moderates, 80. Colman J. Barry, The Catholic Church and German-Americans (Milwaukee, 1957), 7, notes that over $35 \%$ of the German immigrants to the United States between 1865 and 1900 were Catholic.

${ }^{17}$ Lubell, Future American, 142-144, 148-150. 


\section{TABLE VI}

Decrease in Democratic Percentage of Presidential Vote by Iowa Counties, 1936-1940, by Roman Catholic, Lutheran and "German Protestant" Percentages of the Total Church Membership in Each County, $1936 \mathrm{f}$

Percentage of Decrease in the Democratic Percentage of the Presidential All Church Vote in Iowa Counties by Percentage of Church Members in Members in Each of Three Church Categories !

Iowa Counties

in the Churches

Indicated

\begin{tabular}{|c|c|c|c|c|c|c|}
\hline \multirow[b]{2}{*}{$0-7.9 \%$} & \multicolumn{2}{|c|}{ Roman Catholic } & \multicolumn{2}{|c|}{ Lutheran } & \multicolumn{2}{|c|}{ "German Protestant" } \\
\hline & $7.1 \%$ & $(\mathrm{~N}=19)$ & $4.5 \%$ & $(\mathrm{~N}=28)$ & $4.5 \%$ & $(\mathrm{~N}=35)$ \\
\hline $8.0-15.9 \%$ & $8.2 \%$ & $(\mathrm{~N}=22)$ & $7.4 \%$ & $(\mathrm{~N}=$ & $7.0 \%$ & $(\mathrm{~N}=25)$ \\
\hline $16.0-23.9 \%$ & $7.2 \%$ & $(\mathrm{~N}=23)$ & $6.5 \%$ & $(\mathrm{~N}=14)$ & $8.8 \%$ & $(\mathrm{~N}=17)$ \\
\hline $24.0-31.9 \%$ & $6.3 \%$ & $(\mathrm{~N}=12)$ & $8.9 \%$ & $(\mathrm{~N}=23)$ & $10.3 \%$ & $(\mathrm{~N}=12)$ \\
\hline $32.0-78.8 \%$ & $8.5 \%$ & $(\mathrm{~N}=23)$ & $10.2 \%$ & $(\mathrm{~N}=19)$ & $14.5 \%$ & $(\mathrm{~N}=10)$ \\
\hline
\end{tabular}

fUnited States Department of Commerce, Bureau of the Census, Religious Bodies: 1936. Volume I, Summary and Detailed Tables (Washington, 1941), 750-754. Volume II, Part 1, Denominations A to J, 614-618, 626-629; Volume II, Part 2, Denominations $K$ to Z, 872-873, 924-925, 953-958; Official Register, 1937-1938, 312-313; Official Register, 1941-1942, 652-653.

(24.0-78.8\% of all church members) than in counties with similar proportions of Catholics, and declined most of all in counties where equally-large proportions of residents were members of five Protestant churches which were predominantly German in background-the Evangelical Church, the Evangelical and Reformed Church, the United Lutheran Church, the American Lutheran Church, and the Evangelical Lutheran Synod of Missouri, Ohio, and Other States. ${ }^{18}$

In Iowa counties in 1940, nationality and voting behavior corresponded with each other more closely than religion and voting behavior. Iowa counties with large numbers of firstand second-generation German-Americans turned away from

\footnotetext{
${ }^{18}$ Because of mergers, particularly among Lutherans, in some cases the names of these churches no longer represent what they did in the 1936 religious census. These five "German Protestant" denominations are examples of ethnic churches at the time of the third Roosevelt election.
} 
Roosevelt in 1940 regardless of whether the counties were Protestant or Catholic, Lutheran or Methodist.

Among the German Catholic counties which reduced their Democratic presidential vote at least $10.0 \%$ were Carroll, Chickasaw, Dubuque, Jackson, and Plymouth. ${ }^{19}$ German Lutheran counties where Roosevelt's vote fell at least $10.0 \%$ included Bremer, Clayton, Crawford, and Ida. The tendency of German counties to register large decreases in Democratic presidential vote, regardless of religious composition, is evident in such counties as Butler, Franklin, Grundy, Hardin, Lyon, and O'Brien. In each of these counties, fewer than half of all church members were in denominations traditionally associated with German-Americans. In these six German counties where Methodists, Presbyterians, and other non-German denominations predominated, Roosevelt's vote fell as sharply as in German counties where most church members were affiliated with traditionally German denominations.

Table VII illustrates the phenomenon of considerably larger Democratic losses in each class of German counties than in any group of non-German counties, regardless of the religious composition of the counties. On the other hand, the proportion of Roman Catholics-"German Protestants" in each group of counties was unrelated to 1936-1940 voting behavior.

While German counties of varied religious backgrounds registered above-average Democratic decreases, Catholic counties with few German-Americans, e.g., Appanoose, Johnson, Monroe, and Palo Alto, reduced their Democratic presidential vote less than the statewide figure of $6.8 \%$. Table VIII illustrates both the close relationship between German ancestry and 1936-1940 voting behavior, and the lack of any meaningful relationship between Roman Catholicism and voting behavior. As the table indicates, German Catholic counties recorded Democratic decreases more than three times as large as those in Catholic counties with few German-Americans, $12.0 \%$ compared with $3.6 \%$.

${ }^{19}$ Religious Bodies: 1936, I, 750-754; Official Register, 1937-1938, 312-313; and 1941-1942, $652-653$, are the sources for all data regarding the religious composition and the voting behavior of Iowa counties. 


\section{TABLE VII}

Decrease in the Democratic Percentage of the Presidential Vote by Iowa Counties, 1936-1940, According to the German Foreign Stock Percentage of the Total Population, 1930, and the Roman Catholic-"German Protestant" Percentage of Total Church Membership, 1936, in Each Countyg

Roman Catholic- Decrease in the Democratic Percentage of the Presi"German Protestant" dential Vote in Iowa Counties by Percentage of the (RCGP) Percentage German Foreign Stock (GFS) in Each County of Total Church

Membership

\begin{tabular}{|c|c|c|c|}
\hline \% RCGP & $0-10.6 \%$ GFS & $10.7-21.3 \%$ GFS & $21.4-31.9 \%$ GFS \\
\hline & $(\mathrm{N}$ & & $\%($ \\
\hline & 5.4 & & $14.4 \%(\mathrm{~N}=$ \\
\hline $50.0-86.7 \%$ & $4.2 \%(\mathrm{~N}=2)$ & $9.0 \% \quad(\mathrm{~N}=14)$ & $14.7 \%(\mathrm{~N}=12)$ \\
\hline
\end{tabular}

gFifteenth Census, 785-788; Religious Bodies: 1936, I, 750-754; Official Register, 1937-1938, 312-313; Official Register, 1941-1942, 652-653.

\section{TABLE VIII}

Decrease in the Democratic Percentage of the Presidential Vote by Iowa Counties, 1936-1940, According to the German Foreign Stock Percentage of the Total Population, 1930, and the Roman Catholic Percentage of the Total Church Membership in Each County, 1936 ${ }^{\mathrm{h}}$

Roman Catholic (RC) Decrease in the Democratic Percentage of the PresiPercentage of All dential Vote in Iowa Counties by the German Foreign Church Members in Stock (GFS) Percentage of the Total Population Iowa Counties

\begin{tabular}{|c|c|c|c|}
\hline$\% \mathrm{RC}$ & $0-10.6 \%$ GFS & $10.7-21.3 \%$ GFS & $21.4-31.9 \%$ GFS \\
\hline 0 & $5.0 \% \quad(\mathrm{~N}=36)$ & $7.9 \% \quad(\mathrm{~N}=6)$ & $16.9 \% \quad(\mathrm{~N}=9)$ \\
\hline $20.0-3$ & $4.2 \% \quad(\mathrm{~N}=13)$ & $8.7 \% \quad(\mathrm{~N}=16)$ & $13.0 \%(\mathrm{~N}=4)$ \\
\hline $40.0-78.8 \%$ & $3.6 \% \quad(\mathrm{~N}=4)$ & $8.1 \% \quad(\mathrm{~N}=7)$ & $12.0 \% \quad(\mathrm{~N}=4)$ \\
\hline
\end{tabular}

$\mathrm{h}_{\text {Religious Bodies: 1936, I, 750-754; Fifteenth Census, 785-788; Official }}$ Register, 1937-1938, 312-313; 1941-1942, 652-653. 
German Lutheran counties voted considerably less Democratic in 1940 than in 1936, but Lutheran counties with smaller proportions of first- and second-generation GermanAmericans than the statewide figure of $11.2 \%$, recorded Democratic decreases well below the $6.8 \%$ Iowa decrease. Among these non-German Lutheran counties were Audubon, where Roosevelt's vote fell only $4: 0 \%$, Humboldt, $5.7 \%$, Winnebago, $5.1 \%$, and Worth, $4.6 \%$.

Church membership in Iowa corresponded poorly with 1936-1940 voting behavior. The apparent link between membership in certain denominations, e.g., Catholic and Lutheran, and 1936-1940 voting behavior was, in reality, a link between nationality and voting behavior. Catholic counties and Lutheran counties which were also German counties decreased their Democratic presidential vote more than other counties. However, when nationality is controlled, it is clear that German ancestry, rather than religious preference, explains the above-average Democratic decreases in such counties. Catholic and Lutheran counties with few GermanAmericans reduced their Democratic presidential vote less than the statewide figure, indicating clearly that nationality is of more value than religious affiliation in explaining the pattern of Democratic losses in Iowa counties. The data confirms that German ancestry explains the voting behavior of certain Catholic and of certain farm areas more satisfactorily than does religious affiliation or place of residence. At least in Iowa, German Catholic and German farm areas recorded above-average Democratic losses in 1940, while Catholic and farm areas with few German-Americans decreased their Democratic presidential vote less than the statewide figure.

These findings suggest that interpretations of 1936-1940 voting behavior which emphasize the defection of Roman Catholics and of farmers from the Roosevelt coalition base their conclusions upon the voting behavior of German-American Catholic and farm areas. Earlier writers appear to confuse voting behavior in German Catholic and farm areas with voting behavior in all Catholic and farm areas, attributing to 
Catholics and to farmers voting behavior which, at least in Iowa, was unique to German-American Catholic and farm areas of the state.

\section{II}

Determining the motivation of voters is difficult and complex. Nevertheless, analysis of 1936-1940 voting behavior, combined with other approaches, suggests that World War II, rather than the third term or other domestic issues, was the primary reason for the uneven pattern of Democratic decreases in Iowa counties between 1936-1940. However, the impact of the war on voting behavior appears to have been more complex than was suggested in the preceding discussion, which emphasized the defection of German-Americans, and thereby may have implied that the war was a liability to Roosevelt in 1940.

Although World War II decreased Roosevelt's appeal to German-Americans, 1940 survey research indicates that, overall, foreign policy issues may have aided the president's bid for reelection, as some Americans voted for him because of the war, thereby offsetting at least some of the decrease in the Democratic presidential vote among German-Americans. Two types of surveys suggest this conclusion. One asked prospective voters why they preferred Willkie or Roosevelt. The second asked respondents how they would vote with, and without, the existence of war in Europe.

While the reasons given for preferring Willkie or Roosevelt may not be definitive answers to questions of voter motivation, it is noteworthy that prospective Roosevelt voters listed war in Europe as a reason for preferring Roosevelt far more often than prospective Willkie voters listed the same war as a reason for favoring Willkie, or for opposing Roosevelt. In national opinion polls two of the three most frequently expressed reasons for supporting Roosevelt concerned foreign affairs, while only one of the six most frequently expressed reasons for favoring the Republican challenger concerned 
international issues. ${ }^{20}$

To the extent that prospective voters' declared reasons for preferring one candidate or the other are reliable guides to voter motivation, these results appear to suggest the possibility that World War II may have aided, rather than hindered, Roosevelt in 1940. Similar conclusions emerge from contemporary presidential preference polls. Two weeks before the 1940 election, the American Institute of Public Opinion found Roosevelt leading Willkie $54 \%-46 \%$. However, these results were virtually reversed $(53 \%-47 \%)$ when the same sample of prospective voters was asked: "If there were no war in Europe today, which presidential candidate would you vote for, Roosevelt or Willkie?" ${ }^{21}$

If war in Europe aided, rather than hindered, Roosevelt's 1940 reelection bid, and if German-Americans voted considerably more Republican in 1940 than in 1936 because of the war, what groups supported Roosevelt because of the war? The usual answer to this question is that a number of ethnic groups voted for Roosevelt because of his opposition to Germany, and his indirect aid to groups and nations attacked by Hitler. However, as is so often true in American political historiography, statements regarding the 1940 voting behavior of such allegedly pro-Roosevelt groups as Jews, Poles, and Norwegians are offered without evidence that they are based on analysis of either the 1936 or the 1940 voting behavior of the groups in question. ${ }^{22}$

The complexity of the role of the war in 1936-1940 voting behavior is apparent in a study by James McGregor Burns, who notes that "Pro-German and Italian and anti-British elements swung sharply against the President, and these were only partly offset by the Jews, eastern seaboard Yankee inter-

20"Gallup and Fortune Polls," 133.

${ }^{21}$ Daniel Katz, "Public Opinion Polls and the 1940 Election," Public Opinion Quarterly, 5 (March, 1941), 72-73.

${ }^{22}$ Among the authors who maintain that the war in Europe and the Administration's foreign policy aided Roosevelt's candidacy among Jews, Poles, and Norwegians are Lubell, Future American, 137; Lubell, Revolt Moderates, 80; Moscow, Roosevelt and Willkie, 190, 197; Burns, Roosevelt: The Lion, 454-455; Divine, Foreign Policy, 86; and Donald Bruce Johnson, The Republican Party and Wendell Willkie (Urbana, 1960) 163. 
nationalists, and national groups such as Poles and Norwegians who could not forget Hitler's occupation of their 'old country.' " Burns sees the war as both a liability and an asset to Roosevelt's 1940 bid, ". . . Willkie's raising of the war issue did cut into Roosevelt's vote." Yet, "Poll after poll showed that the sharper the crisis, the more the voters clung to Roosevelt. The emergency situation seemed wholly to counteract Willkie's third-term warnings." ${ }_{23}$

If Burns and other students of the 1940 election are correct in their belief that because of World War II Roosevelt lost more votes among some ethnic groups than he gained among others, and if Gallup is correct in his conclusion that the war enhanced Roosevelt's standing with the voters, the apparent incongruity may lie with the supposedly non-ethnic majority, native born whites of native parentage, many of whose European origins go back to Great Britain and Northern Ireland.

The role of Americans of British descent in the election of 1940 has already been suggested by Lubell who maintains that ". . . our oldest ethnic element, the Yankee descendants of the original English settlers," ${ }^{24}$ voted more heavily Democratic in 1940 than in 1936, thereby increasing Roosevelt's percentage of the vote in five of the six New England states, at the same time that the nationwide Democratic presidential vote declined $6.1 \%$. However, Lubell offers no evidence to support his conclusion that "Yankee descendants of the original English settlers" accounted for the increased Democratic presidential vote in New England in 1940. Moreover, even a brief reference to census data ${ }^{25}$ indicates that New England's demographic history is much more complex than Lubell assumes when he implies that the bulk of 1940 New England voters were "Yankees."

Examination of British-American voting behavior in Iowa

${ }^{23}$ Burns, Roosevelt: The Lion, 454-455.

${ }^{24}$ Lubell, Future American, 135.

${ }^{25}$ Fifteenth Census, III, Part 1, 355-360, 1027-1031, 1089-1101; Part 2, 164-168, 766-769, 1128-1132. 
can help answer questions about the response of that group to World War II. Because British immigrants and their descendants were a large majority of all whites during the first 200 years of American history, they constituted a majority of all third- and later-generation whites well into the twentieth century $-59.4 \%$ in $1920,55.3 \%$ in 1930 , and $51.2 \%$ in $1940 .{ }^{26}$ Therefore, the proportion of native whites of native parentage in counties, cities, and states is a useful index to the size of the British-American segment of the population at the time of the third Roosevelt election.

In Iowa counties with the largest proportions of third- and later generation Americans, and thus of Americans of British descent, the Democratic presidential vote declined considerably less than in counties with the smallest proportions of residents whose families had been in the United States for at least three generations. As Table IX discloses, Roosevelt's vote declined less than half as much $(4.8 \%$ compared with $10.6 \%)$ in Iowa counties with the largest proportions $(80.1 \%-93.4 \%$ of the total population) of third- and later-generation Americans as it did in counties with the smallest proportions $(39.6 \%$ 53-.0\%) of old stock Americans. In the seven counties where over $90.0 \%$ of the population was at least third-generation, the Democratic presidential vote declined only $2.4 \%$, little more than one-third the statewide decline of $6.8 \%$, and less than one-sixth the $16.0 \%$ decline in the nine most German counties. The seven counties and their third-generation populations were Clarke $(91.3 \%)$, Davis $(92.7 \%)$, Decatur (92.4\%), Ringgold $(91.3 \%)$, Van Buren $(90.1 \%)$, Warren $(90.4 \%)$, and Wayne $(93.4 \%) .27$

The 1936-1940 voting behavior of the most British

\footnotetext{
${ }^{26}$ For information regarding the relative proportions of British-Americans and of other European groups in the white population of the United States at various times since 1790, see "Report of Committee on Linguistic and National Stocks in the Population of the United States," in Annual Report of the American Historical Association for the Year 1931 (Washington, 1932), Volume I, 108-124, and U.S. Bureau of the Census, Historical Statistics of the United States, Colonial Times to 1957 (Washington, 1960), 7, 56-57. U.S. Bureau of the Census, unpublished data, for the proportion of British-Americans among native whites of native parentage in 1920,1930 , and 1940.

${ }^{27}$ Fifteenth Census, Part 1, 767-773.
} 
counties was largely the reverse of that in the most German counties (Table II). The very different patterns of 1936-1940 voting behavior in the two types of counties are convincing testimony that World War II was a determining factor in voting behavior in the Hawkeye state in the Roosevelt-Willkie contest.

\section{TABLE IX}

Decrease in the Democratic Percentage of the Presidential Vote, 1936-1940, by Iowa Counties, by Native Born Whites of Native Parentage Percentage of the Total Population, 1930

\begin{tabular}{crl}
$\begin{array}{c}\text { Native Born Whites } \\
\text { of Native Parentage }\end{array}$ & $\begin{array}{r}\text { Decrease in Democratic Percentage } \\
\text { of the Presidential Vote }\end{array}$ \\
\cline { 2 - 3 } $39.6-53.0 \%$ & $10.6 \%$ & $(\mathrm{~N}=6)$ \\
$53.1-66.5 \%$ & $10.1 \%$ & $(\mathrm{~N}=36)$ \\
$66.6-80.0 \%$ & $5.6 \%$ & $(\mathrm{~N}=34)$ \\
$80.1-93.4 \%$ & $4.8 \%$ & $(\mathrm{~N}=23)$
\end{tabular}

iFifteenth Census, Part I, 767-773; Official Register, 1937-1938, 312-313; Official Register, 1941-1942, 652-653.

Although the outbreak of war in Europe and the apparently strong feelings of many Americans toward that war appear to explain much of the variety in 1936-1940 voting behavior, the unsettled state of American politics in the 1930s could also have contributed to the uneven pattern of Democratic losses at the end of the decade. Both the landslide proportions of Roosevelt's 1936 victory and the relatively large amount of ticket-splitting which occurred in that election suggest the possibility that Democratic losses in 1940 may have been concentrated in traditionally Republican areas, where large numbers of voters had favored Roosevelt over both Hoover and Landon without, however, renouncing the Republican party completely. Voters in these traditionally Republican areas may have returned to the GOP in large numbers in 1940 , thereby contributing to both the increase in the Republican presidential vote and to the uneven pattern of Republican gains in Iowa counties between 1936 and 1940. 
However, this possible explanation of the variety in 1936 1940 voting behavior in Iowa counties receives no support from an examination of voting data. In fact, Table $\mathbf{X}$ demonstrates that Iowa counties which were traditionally the most Republican, and those which were traditionally the least Republican, based on the Republican percentage of the vote for state auditor in the six elections (1920-1930) preceding the political upheaval of the Great Depression, registered similar decreases in their Democratic presidential vote between 1936 and 1940. The two categories of counties which had been the most Republican in the 1920 s recorded Democratic decreases of $6.8 \%$ and $7.3 \%$ between 1936 and 1940 . The two least Republican groups of counties registered similar Democratic decreases, $6.5 \%$ and $8.7 \%$. The absence of any marked difference in the 1936-1940 voting behavior of counties which had been the most Republican in the state, 1920-1930, and of counties which had been the least Republican in the same period, suggests that the traditional (pre-depression) political allegiance of Iowa counties offers no explanation for the uneven pattern of decreases in the Democratic presidential vote between the second and the third Roosevelt elections.

\section{TABLE $X$}

Decrease in the Democratic Percentage of the Presidential Vote, 1936-1940, by the Traditional (pre-depression) Strength of the Republican Party in Iowa Counties, based on Republican Vote for State Auditor, 1920-1930 Inclusivej

\begin{tabular}{c}
$\begin{array}{c}\text { Republican Vote for } \\
\text { State Auditor, } \\
1920-1930\end{array}$ \\
\hline $44.3-55.6 \%$ \\
$55.7-67.0 \%$ \\
$67.1-78.3 \%$ \\
$78.4-89.5 \%$
\end{tabular}

\begin{tabular}{cl}
$\begin{array}{c}\text { Decrease in the Democratic } \\
\text { Presidential Vote, } \\
1936-1940\end{array}$ \\
\hline $6.5 \%$ & $(\mathrm{~N}=6)$ \\
$8.7 \%$ & $(\mathrm{~N}=29)$ \\
$6.8 \%$ & $(\mathrm{~N}=42)$ \\
$7.3 \%$ & $(\mathrm{~N}=22)$
\end{tabular}

jOfficial Register, 1921-1922, 461-462; 1923-1924, 497-498; 1925-1926. 542-543; 1927-1928, 460-461; 1929-1930, 426-427; 1931-1932, 440-441. 
The absence of a significant relationship between the size of the 1936-1940 decrease in the Democratic presidential vote, and all but two of the other factors which have been examined, points strongly to several interrelated conclusions regarding 1936-1940 voting behavior in Iowa. First, German immigrants and their children decreased their Democratic presidential vote more than any other group in the state. Second, Iowa voters of British descent reduced their support for Roosevelt less than other groups of Iowans. Third, although the Democratic presidential vote decreased somewhat more among Catholics, farmers, and other non-urban Iowans than it did among Protestants, non-farmers, or Iowans who lived in more urban areas, these differences reflected the larger proportions of Catholics, of farmers, and of other non-urban Iowans who were of German descent rather than voting behavior which was unique to Catholics as Catholics, to farmers as farmers, or to farm and small town residents as ruralites. Although the Democratic presidential vote fell somewhat more in rural counties with given proportions of German-Americans than in either urban counties or in cities with similar percentages of first- and second-generation Germans, change in voting behavior between 1936 and 1940 corresponded more closely with the size of the German-American population than with the size of the community. Fourth, and last, traditional (pre-depression) county voting patterns have no explanatory value in connection with changes in the presidential vote between 1936 and 1940. 
Copyright of Annals of Iowa is the property of State of Iowa, by \& through the State Historical Society of Iowa and its content may not be copied or emailed to multiple sites or posted to a listserv without the copyright holder's express written permission. However, users may print, download, or email articles for individual use. 